\title{
REDUKSI BESI (Fe) DAN MANGAN (Mn) PADA AIR TANAH MENGGUNAKAN MEDIA FILTRASI MANGANESE GREENSAND DAN ZEOLIT TERPADUKAN RESIN
}

\author{
Novia Rahmawati ${ }^{1)}$ dan Sugito $^{2)}$ \\ 1) dan 2) Program Studi Teknik Lingkungan, Fakultas Teknik Sipil dan Perencanaan \\ Universitas PGRI Adi Buana Surabaya \\ Email : nophyarahmawati@yahoo.co.id
}

\begin{abstract}
Abstrak
Air tanah mengandung ion terlarut seperti Besi ( $F e)$, Mangan (Mn), dan beberapa senyawa anorganik lainnya. Terlarutnya Fe dan Mn dalam air menyebabkan warna air tersebut berubah menjadi kuning coklat setelah terjadi kontak dengan udara. Diperlukan teknologi untuk menurunkan kandungan Fe dan Mn pada air tanah agar layak dikonsumsi oleh masyarakat. Penelitian ini bertujuan untuk mengaji efektivitas removal Fe dan Mn menggunakan media filtrasi Manganese greendsand dan Zeolit terpadukan resin pada air tanah. Variabel penelitian adalah kombinasi jenis media dan waktu operasi filtrasi yaitu: 15, 30, dan 45 menit. Sampel yang digunakan adalah sampel buatan dengan kandungan $\mathrm{Fe}=5,316 \mathrm{mg} / \mathrm{L}$ dan $\mathrm{Mn}=2,533 \mathrm{mg} / \mathrm{L}$. Instalasi filtrasi terbuat dari pipa PVC dengan diameter 4 inchi dengan ketinggian $100 \mathrm{~cm}$ dan menggunakan aliran upflow. Analisis Fe menggunakan metoda ortho-phenantrolin secara spektrofotometer, sedangkan analisis Mn menggunakan metode persulfat secara permanganometri. Konsentrasi $\mathrm{Fe}$ dan Mn setelah pengolahan mengalami penurunan. Pada media Manganese Greensand konsentrasi Fe menjadi 0,316 mg/L dan 0,017 mg/L untuk Mn. Pada media Zeolit konsentrasi Fe menjadi 1,424 mg/L dan 0,049 mg/L untuk Mn. Media Manganese Greensand memiliki efektivitas removal sebesar $94 \%$ untuk Fe dan $99 \%$ untuk removal Mn. Sedangkan media Zeolit memiliki efektivitas removal sebesar $73 \%$ untuk parameter Fe dan $98 \%$ untuk Mn.
\end{abstract}

Kata kunci: Filtrasi, Ion Exchange, Manganese Greensand, Zeolit.

\begin{abstract}
Ground water contains dissolved ion such as Iron (Fe),Manganese (Mn), and several compounds anorganic other. Dissolved Fe and Mn in the water that causes the water color changed to yellow brown after a while contact with air.Therefore we need the technology to process the content of $\mathrm{Fe}$ and $\mathrm{Mn}$ in groundwater in order to be consumed by the public. This research was aim to assess the effectiveness of the removal of Fe and Mn in groundwater using manganese greendsand and zeolite combine with resin. The variables are combination types of media and operating time (15,30, dan 45 minutes). Samples synthetic with Fe content 5,316 mg/L and 2,533 $\mathrm{mg} / \mathrm{L}$ of Mn contnent. Installing filtration made from PVC pipe with a diameter of 4 inches with a height of $100 \mathrm{~cm}$ and using upflow flow system. Fe analysis using the method of ortho - phenantrolin in spectrophotometer, and Mn analysis method using permanganometri persulfate. The concentrartion of $\mathrm{Fe}$ and $\mathrm{Mn}$ after treatment was reduce. In the manganese greensand Fe concentration became 0,316 $\mathrm{mg} / \mathrm{L}$ and $0,017 \mathrm{mg} / \mathrm{L}$ for Mn. The concentration of $\mathrm{Fe}$ in Zeolite became $1.424 \mathrm{mg} / \mathrm{L}$ and 0,049 $\mathrm{mg} / \mathrm{L}$ for Mn. Percentage of removal of Fe and Mn with manganese greensand were $94 \%$ and $99 \%$. Percentage of removal of Fe and Mn with Zeolite were $73 \%$ and $98 \%$.
\end{abstract}

Key Words : Filtration, Ion Exchange, Manganese Greensand, Zeolit. 
Novia Rahmawati dan Sugito : Reduksi Besi (Fe) dan Mangan (Mn) pada Air Tanah Menggunakan Media Filtrasi Manganese Greensand dan Zeolit Terpadukan Resin

\section{PENDAHULUAN}

Data dari Badan Pusat Statistik Kota Surabaya tahun 2013, persentase banyaknya rumah tangga dan sumber air minum yang digunakan di Surabaya yaitu : air kemasan 78 $\%$, ledeng (PDAM) $22 \%$, dan air tanah (baik dengan sumur pompa, sumur terlindung maupun tidak terlindung) $0,09 \%$. Hal ini setara dengan jumlah penduduk kota Surabaya sebanyak 2.556 jiwa yang menggunakan air tanah sebagai sumber air minum. Air tanah mengandung kation terlarut seperti Besi $(\mathrm{Fe})$, Mangan (Mn), dan beberapa senyawa anorgnik lainnya. Adanya kandungan $\mathrm{Fe}$ dan Mn dalam air yang menyebabkan warna air tersebut berubah menjadi kuning - coklat setelah beberapa saat kontak dengan udara.sehingga belum layak untuk dikonsumsi. Oleh karena itu diperlukan teknologi untuk mengolah kandungan Besi dan Mangan pada air tanah.

Besi terdapat secara alami di dalam air dalam bentuk terlarut sebagai senyawa ferro atau besi-II $\left(\mathrm{Fe}^{2+}\right)$; ferri atau besi-III $\left(\mathrm{Fe}^{3+}\right)$; tersuspensi sebagai butir koloid (diameter $<1$ $\mathrm{mm})$ atau lebih besar, seperti $\mathrm{Fe}(\mathrm{OH})_{3}$; dan tergabung dengan zat organik atau zat padat yang anorganik seperti tanah liat dan partikel halus terdispersi. Senyawa besi-II dalam air yang sering dijumpai di alam adalah $\mathrm{FeO}$, $\mathrm{FeSO}_{4}, \mathrm{FeSO}_{4} .7 \mathrm{H}_{2} \mathrm{O}, \mathrm{FeCO} 3, \mathrm{Fe}(\mathrm{OH})_{2}$, dan $\mathrm{FeCl}_{2}$. Sedangkan senyawa besi-III yang sering dijumpai adalah $\mathrm{FePO} 4, \mathrm{Fe}_{2} \mathrm{O}_{3}, \mathrm{FeCl}_{3}$, $\mathrm{Fe}(\mathrm{OH}) 3$. (Lenore et al., 2005; Said, 2003). Masalah utama yang ditimbulkan akibat adanya kandungan besi yang tinggi pada air adalah mengenai estetika air. Kandungan besi dalam air akan memberikan warna karat pada air, menimbulkan noda berwarna coklat kemerahan pada pipa ledeng, porselin, piring maupun pakaian serta memberikan rasa logam sehingga tidak enak jika dikonsumsi. Penurunan kandungan Besi dalam air tanah dapat diturunkan sampai dengan $80 \%$ dengan menggunakan resin penukar ion, (Sugito dan Sembodo, B. P., 2014).

Mangan terlarut dalam air tanah dan air permukaan yang sedikit oksigen. Mangan bisa membentuk oksida yang tidak larut dan menghasilkan endapan bila terpapar dengan oksigen, sehingga menimbulkan masalah berupa penampilan fisik air yang mengganggu. Mangan umumnya berada dalam keadaan senyawa dengan berbagai macam tingkat oksidasi atau valensi. Di dalam hubungannya dengan kualitas air yang sering dijumpai adalah senyawa mangan dengan valensi 2, valensi 4, valensi 6. Mangan di dalam senyawa $\mathrm{MnCO} 3, \quad \mathrm{Mn}(\mathrm{OH})_{2}$ mempunyai valensi dua, zat tersebut relatif sulit larut dalam air, tetapi untuk senyawa $\mathrm{Mn}$ seperti garam $\mathrm{MnCl}_{2}, \mathrm{MnSO}_{4}, \mathrm{Mn}\left(\mathrm{NO}_{3}\right)_{2}$ mempunyai kelarutan yang besar di dalam air (Lenore et al., 2005; Said, 2003; Crossgrove \& Wei Zheng, 2004).

Manganese greensand adalah mineral yang dapat menukar electron sehingga dapat mengoksidasi besi atau mangan yang larut dalam air menjadi bentuk yang tak larut sehingga dapat dipisahkan dengan filtrasi. Manganese greensand $\left(\mathrm{K}_{2} \mathrm{Z} . \mathrm{MnO}_{2} . \mathrm{Mn}_{2} \mathrm{O}_{7}\right)$ dapat juga berfungsi sebagai katalis dan pada waktu yang bersamaan besi dan mangan yang ada dalam air teroksidasi menjadi bentuk ferri - oksida dan mengoksida yang tak larut dalam air. Menurut Said (2003) reaksi kimianya adalah sebagai berikut :

$\mathrm{K}_{2} \mathrm{Z} \cdot \mathrm{MnO} \cdot \mathrm{Mn}_{2} \mathrm{O}_{7}+4 \mathrm{Fe}\left(\mathrm{HCO}_{3}\right) \rightarrow 2 \mathrm{~K}_{2} \mathrm{Z}+3$ $\mathrm{MnO}_{2}+2 \mathrm{Fe}_{2} \mathrm{O}_{3}+8 \mathrm{CO}_{2}+4 \mathrm{H}_{2} \mathrm{O}$

$\mathrm{K}_{2} \mathrm{Z} \cdot \mathrm{MnO} \cdot \mathrm{Mn}_{2} \mathrm{O}_{7}+2 \mathrm{Mn}\left(\mathrm{HCO}_{3}\right)_{2} \rightarrow \mathrm{K}_{2} \mathrm{Z}+5$ $\mathrm{MnO}_{2}+4 \mathrm{CO}_{2}+2 \mathrm{H}_{2} \mathrm{O}$

Reaksi penghilangan besi dan mangan dengan mangan zeolit tidak sama dengan proses pertukaran ion, tetapi merupakan reaksi dari $\mathrm{Fe}^{2+}$ dan $\mathrm{Mn}^{2+}$ dengan oksida mangan tinggi ( higher mangan oxide ).Filtrat yang terjadi mengandung ferri - oksida dan mangan - oksida yang tak larut dalam air dan dapat dipisahkan dengan pengendapan dan penyaringan. Selama proses berlangsung kemampuan reaksinya makin lama makin berkurang dan akhirnya jenuh. Keunggulan proses ini adalah mangan zeolit dapat berlaku sebagai buffer (penyangga) (Said,2003)

Zeolit adalah mineral kristal alumina silica tetrahidrat berpori yang mempunyai struktur kerangka tiga dimensi, terbentuk oleh tetrahedral $\left[\mathrm{SiO}_{4}\right]^{4-}$ dan $\left[\mathrm{AlO}_{4}\right]^{5-}$ yang saling terhubungkan oleh atom-atom oksigen sedemikian rupa, sehingga membentuk kerangka tiga dimensi terbuka yang mengandung kanal-kanal dan rongga-rongga, yang didalamnya terisi oleh ion-ion logam, biasanya adalah logam-logam alkali atau alkali tanah dan molekul air yang dapat bergerak bebas (Chetam, 1992). Sifat zeolit sebagai 
Novia Rahmawati dan Sugito : Reduksi Besi (Fe) dan Mangan (Mn) pada Air Tanah Menggunakan Media Filtrasi Manganese Greensand dan Zeolit Terpadukan Resin

adsorben dan penyaring molekul, dimungkinkan karena struktur zeolit yang berongga, sehingga zeolit mampu menyerap sejumlah besar molekul yang berukuran lebih kecil atau sesuai dengan ukuran rongganya. Sedangkan sifat zeolit sebagai penukar ion karena adanya kation logam alkali dan alkali tanah. Kation tersebut dapat bergerak bebas didalam rongga dan dapat dipertukarkan dengan kation logam lain dengan jumlah yang sama. Akibat struktur zeolit berongga, anion atau molekul berukuran lebih kecil atau sama dengan rongga dapat masuk dan terjebak.

Permasalahan dalam penelitian ini, yaitu : "Berapakah efektivitas removal Fe dan Mn menggunakan media filtrasi manganese greensand dan zeolit terpadukan resin penukar ion pada air tanah?". Tujuan dalam penelitian ini adalah mengaji efektivitas removal Fe dan $\mathrm{Mn}$ menggunakan media manganese greendsand dan zeolit terpadukan resin penukar ion pada air tanah. Manfaat dari penelitian ini adalah untuk menghasilkan air yang layak dikonsumsi bagi masyarakat.

Secara umum penelitian terdahulu menggunakan teknologi aerasi, filtrasi dan kombinasi antara filtrasi dengan aerasi untuk menurunkan kadar Fe dan Mn. Teknologi kombinasi antara filtrasi dengan aerasi memiliki efisiensi sebesar $62 \%$ untuk $\mathrm{Fe}$ dan 100\% untuk Mn, (Anika, 2013). Pada penelitian ini teknologi yang akan digunakan oleh peneliti adalah kombinasi antara filtrasi dengan resin penukar ion. Diharapkan kombinasi kedua teknologi tersebut mampu menurunkan kadar Besi dan Mangan pada air sumur gali secara signifikan.

Dalam penelitian ini media yang digunakan adalah media manganese greensand dan zeolit terpadukan resin penukar ion. Alasan dipilihnya media zeolit dalam penelitian ini adalah karena memiliki efektifitas yang tinggi dalam penyerapan kadar Besi yakni sebesar $62 \%$ dan $99 \%$ untuk Mangan (Anika, 2013), harganya relatif murah, dan mudah diperoleh di pasaran.

Penggunaan media manganese greensand dipilih karena memiliki efektifitas yang tinggi dalam penyerapan kadar Besi yakni sebesar $93 \%$ dan $97 \%$ untuk Mangan (Winda, 2002), harganya relatif murah, dan mudah diperoleh di pasaran. Penggunaaan teknologi resin penukar ion dipilih karena mudah dioperasikan dan resin dapat diregenerasi kembali apabila mengalami kejenuhan.

\section{METODE}

\section{Rancangan Penelitian}

Pada penelitian ini dilakukan kajian sejauh mana efektivitas removal media filtrasi manganese greensand dan zeolit terpadukan resin penukar ion dengan variabel jenis media dan lama waktu operasi dalam menurunkan konsentrasi Fe dan Mn dalam air tanah. Rancangan penelitian secara rinci pada Gambar 1 berikut 


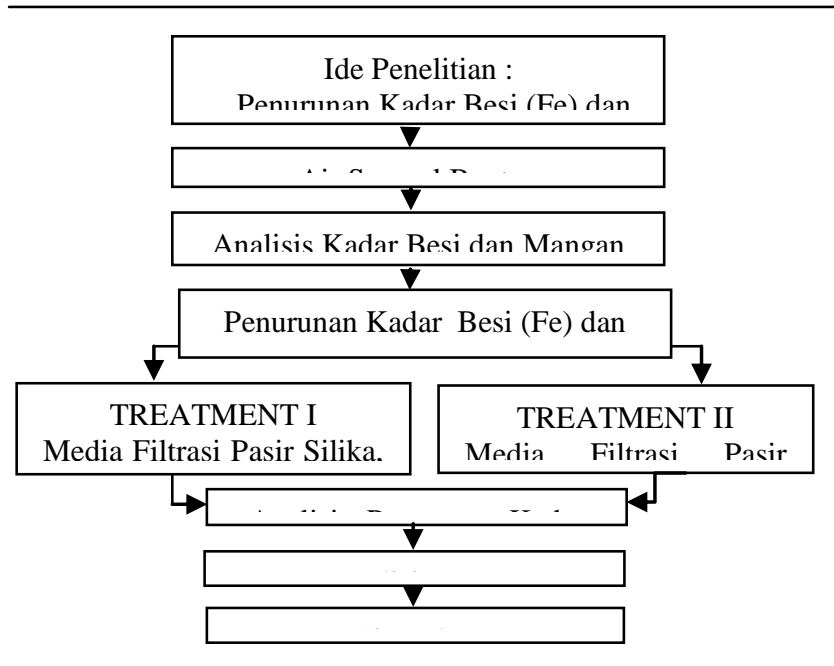

Gambar 1. Rancangan Penelitian

A. Populasi dan Jumlah Sampel

1. Populasi

Populasi dalam penelitian ini adalah air sampel buatan dengan konsentrasi Fe sebesar $5 \mathrm{mg} / \mathrm{L}$ dan konsentrasi Mn sebesar $2 \mathrm{mg} / \mathrm{L}$. Penggunaan air sampel buatan dalam penelitian ini karena dikhawatirkan terjadinya fluktuasi konsentrasi $\mathrm{Fe}$ dan $\mathrm{Mn}$ dalam air sumur gali selama penelitian yang disebabkan oleh perubahan faktor cuaca.

2. Jumlah Sampel

Sampel penelitian adalah sebagian dari air sampel buatan. Setelah dilakukan proses filtrasi dan pertukaran ion, jumlah sampel yang diambil sebanyak 16 sampel. Sampel tersebut terdiri dari 8 sampel dengan treatment menggunakan media manganese greensand dan 8 sampel dengan treatment menggunakan media zeolit. Berdasarkan prosedur pengujian Besi dan Mangan yang digunakan, volume yang dibutuhkan setiap sampel sebanyak $\pm 600 \mathrm{ml}$. Replikasi sampel dilakukan sebanyak 2 kali, karena bertujuan untuk mendapatkan data yang relevan sehingga data yang diperoleh mewakili (representative) terhadap kondisi sampel.

\section{B. Alat dan Bahan}

Dalam penelitian ini, peneliti menggunakan rangkaian instalasi alat dan bahan seperti yang tersaji pada gambar 2 berikut : 


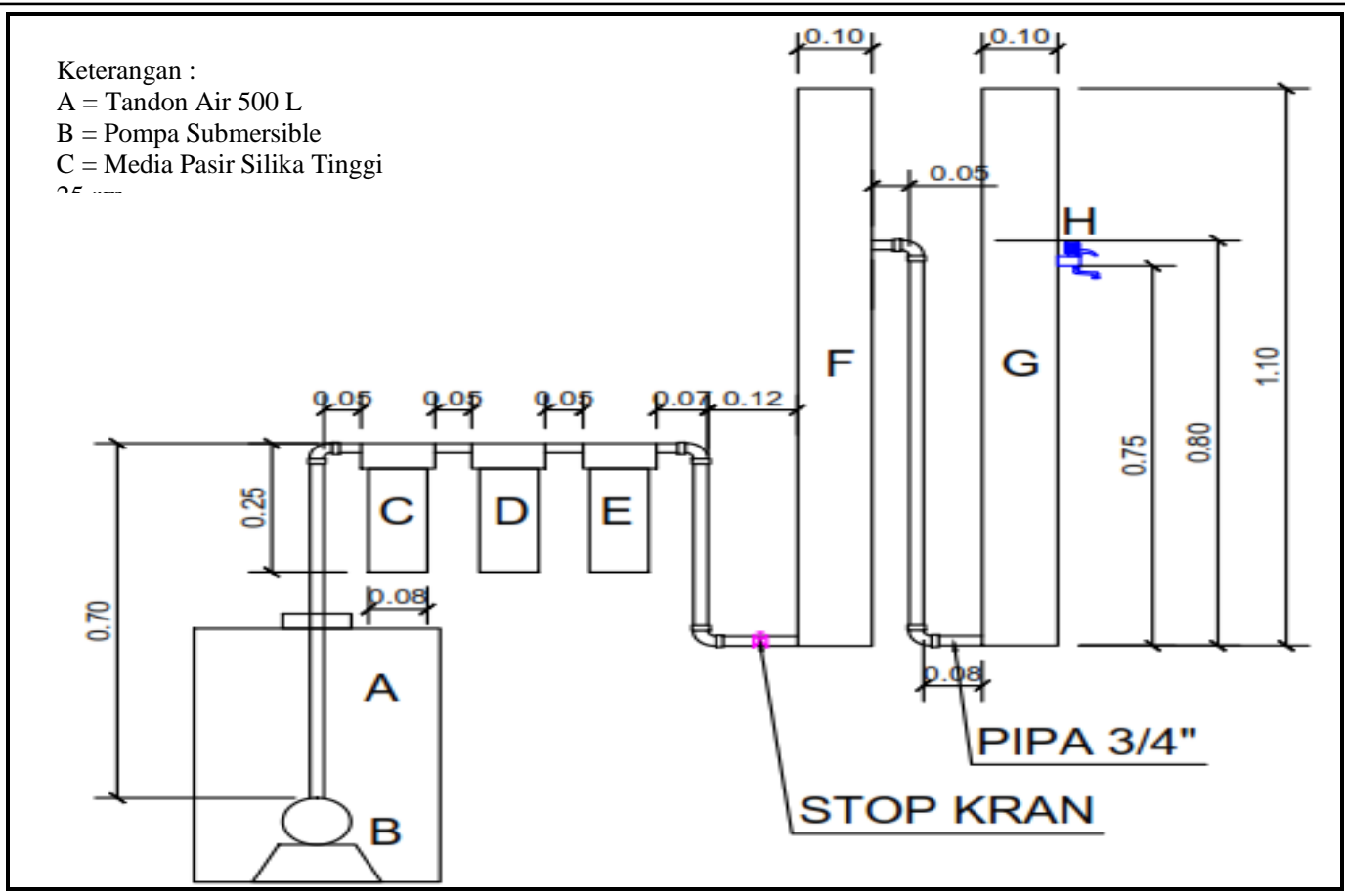

Gambar 2.Instalasi Filtrasi Terpadukan Resin

Langkah - Langkah Percobaan

a) Merangkai instalasi filtrasi seperti pada gambar 2.

b) Mengukur porositas media pasir, karbon aktif, zeolit, dan mengukur debit empiris. Debit yang digunakan dalam penelitian ini sebesar 0,419 L/menit.

c) Menimbang $\mathrm{FeSO}_{4}$ sebanyak 0,68 gr dan $\mathrm{MnSO}_{4}$ sebanyak 0,27 gr kemudian dilarutkan dalam 50 Liter air kran. Larutan ini selanjutnya akan disebut sebagai air sampel.

d) Sampel ditampung dalam bak penampung kemudian dipompa dengan debit $25 \mathrm{~L} /$ jam (aliran upflow) menuju instalasi filtrasi terpadukan resin. Mencatat waktu yang dibutuhkan untuk mengisi seluruh bagian pada instalasi filtrasi terpadukan resin penukar ion.

e) Setelah seluruh bagian instalasi terisi dengan sampel, maka selanjutnya dilakukan proses running.

f) Sampel menuju housing filter pertama (C) yang berisikan media pasir silika untuk proses filtrasi.

g) Selanjutnya sampel menuju housing filter (D) yang berisikan media manganese greensand zeolit kemudian menuju housing filter (E) dengan media karbon aktif yang memiliki ketinggian media masing masing $25 \mathrm{~cm}$ untuk dilakukan filtrasi.

h) Setelah sampel melewati ketiga media filtrasi, selanjutnya sampel dialirkan menuju housing resin anion $(\mathrm{F})$ dan resin kation $(\mathrm{G})$ untuk dilakukan pertukaran ion. Pengambilan sampel saat waktu operasi alat pada menit ke 15, 30, dan 45 menit melalui kran $\mathrm{H}$.

Sampel hasil dari proses filtrasi terpadukan resin diuji di laboratorium untuk mengetahui penurunan konsentrasi Besi $(\mathrm{Fe})$ dan Mangan $(\mathrm{Mn})$ pada air sampel. Analisis Besi $(\mathrm{Fe})$ dalam penelitian ini menggunakan metode ortho-phenantrolin secara spketrofotometri. Sedangkan analisis Mangan (Mn) dianalisa menggunakan metode persulfat secara permanganometri.

i) Replikasi dilakukan sebanyak 2 kali. Setiap pengulangan seluruh media yang terdapat pada instalasi diganti dengan media yang baru. Sedangkan untuk resin anion dan resin kation dilakukan proses backwash dengan arah aliran down flow menggunakan air produk hasil treatment. Hal ini bertujuan untuk mencegah terjadinya kejenuhan pada media yang dapat menyebabkan turunnya efektivitas removal. 
Novia Rahmawati dan Sugito : Reduksi Besi (Fe) dan Mangan (Mn) pada Air Tanah Menggunakan Media Filtrasi Manganese Greensand dan Zeolit Terpadukan Resin

\section{Metode Analisis Data}

Data yang terkumpul dalam penelitian ini dipilah berdasarkan kategorinya, kemudian diolah dalam bentuk tabulasi dan disajikan dalm bentuk tabel, grafik, dan prosentase.

\section{HASIL DAN PEMBAHASAN}

A. Grafik Efektivitas Removal Fe

Gambar 3 berikut ini adalah grafik efektivitas removal $\mathrm{Fe}$ setelah treatment menggunakan media filtrasi manganese greensand dan zeolit terpadukan resin penukar ion :

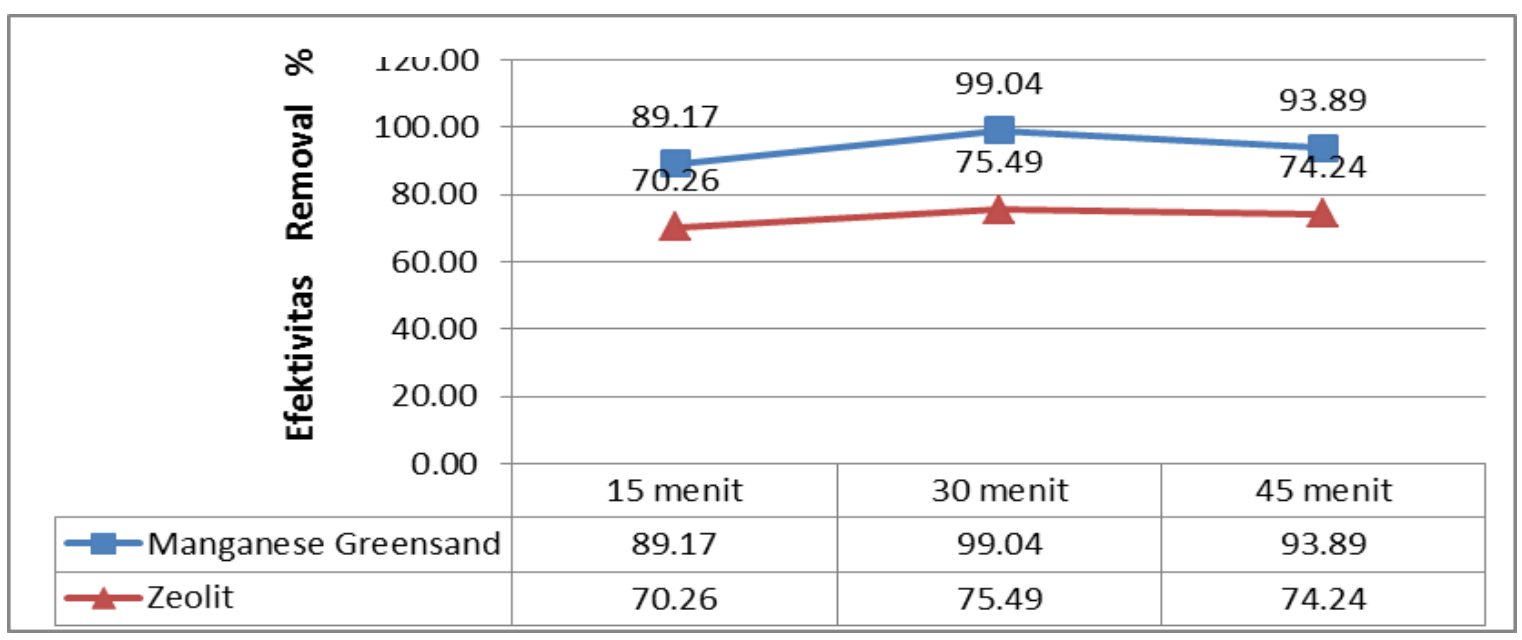

Gambar 3. Grafik Penurunan Fe Setelah Treatment

Gambar 3 menunjukkan gambaran efektivitas removal $\mathrm{Fe}$ yang dinyatakan dalam prosentase. Penurunan konsentrasi Fe dengan treatment manganese greensand dan zeolit paling optimal terlihat pada pengambilan sampel saat waktu operasi menit ke 30, yakni sebesar $99 \%$ untuk media manganese greensand dan $75 \%$ dengan media zeolit. Sedangkan pada pengambilan sampel saat waktu operasi menit ke 45, efektivitas removal Fe pada media manganese greensand terlihat menurun yakni sebesar $94 \%$ dan pada media zeolit sebesar $74 \%$.

Manganese greensand adalah mineral yang dapat menukar electron sehingga dapat mengoksidasi besi atau mangan yang larut dalam air menjadi bentuk yang tak larut sehingga dapat dipisahkan dengan filtrasi. Manganese greensand $\left(\mathrm{K}_{2} \mathrm{Z} . \mathrm{MnO}_{2} \cdot \mathrm{Mn}_{2} \mathrm{O}_{7}\right)$ dapat juga berfungsi sebagai katalis dan pada waktu yang bersamaan besi dan mangan yang ada dalam air teroksidasi menjadi bentuk ferri - oksida dan mengoksida yang tak larut dalam air. Menurut Said (2003) reaksi kimianya adalah sebagai berikut :

$\mathrm{K}_{2} \mathrm{Z} \cdot \mathrm{MnO} \cdot \mathrm{Mn}_{2} \mathrm{O}_{7}+4 \mathrm{Fe}\left(\mathrm{HCO}_{3}\right) \rightarrow 2 \mathrm{~K}_{2} \mathrm{Z}$ $+3 \mathrm{MnO}_{2}+2 \mathrm{Fe}_{2} \mathrm{O}_{3}+8 \mathrm{CO}_{2}+4 \mathrm{H}_{2} \mathrm{O}$

Pada penelitian ini zeolit yang digunakan adalah zeolit yang tidak diaktivasi terlebih dahulu. Zeolit adalah mineral kristal alumina silica tetrahidrat berpori dan berongga, yang didalamnya terisi oleh ion-ion logam, biasanya adalah logam alkali atau alkali tanah dan molekul air yang dapat bergerak bebas (Chetam, 1992). Endapan Fe yang terbentuk kemudian akan ditukar dengan kation pada unsur logam golongan IA atau IIA (alkali dan alkali tanah) seperti $\mathrm{K}^{+}, \mathrm{Na}^{+}, \mathrm{Ca}^{+}$ dan $\mathrm{Mg}^{2+}$ Persamaan reaksi pertukaran ion pada zeolit yaitu :

Zeolit. $\mathrm{Na}^{+}+\mathrm{Fe}^{3+} \rightarrow$ Zeolit.Fe ${ }^{3+}+\mathrm{Na}^{+}$

Gambar 4 menunjukkan bahwa media manganese greensand lebih efektif untuk menurunkan Fe daripada media zeolit. Hal ini dikarenakan ukuran partikel manganese greensand lebih kecil daripada media zeolit. Pada penelitian ini manganese greensand yang digunakan memiliki diameter $0,35 \mathrm{~mm}$, sedangkan diameter zeolit yang digunakan adalah $1 \mathrm{~mm}$. Menurut Purwanti (2010) luas permukaan mempercepat laju reaksi karena semakin luas permukaan zat, maka semakin banyak bagian zat yang saling bertumbukan dan semakin besar peluang adanya tumbukan efektif untuk menghasilkan perubahan. Semakin luas permukaan zat, semakin kecil ukuran partikel zat. Dengan kata lain semakin kecil ukuran partikel zat, maka reaksi pun 
Novia Rahmawati dan Sugito : Reduksi Besi (Fe) dan Mangan (Mn) pada Air Tanah Menggunakan Media Filtrasi Manganese Greensand dan Zeolit Terpadukan Resin

akan semakin cepat. Penyebab kedua adalah karena ukuran zeolit besar maka jumlah zeolit yang digunakan dalam housing filter lebih sedikit daripada penggunaan manganese greensand dengan kata lain jumlah zeolit terhadap air di dalam housing filter menjadi sedikit. Penyebab ketiga adalah karena zeolit yang digunakan tidak diaktivasi terlebih dahulu, namun hanya dicuci dengan aquades,sedangkan manganese greensand adalah zeolit sintetis yang permukaannya telah dilapisi oleh mangan oksida tinggi. Ketiga hal inilah yang menyebabkan efektivitas zeolit lebih rendah daripada manganese greensand.

Gambar 3 juga menjelaskan bahwa efisiensi removal $\mathrm{Fe}$ menggunakan media manganese greensand dan zeolit terpadukan resin penukar ion mengalami sedikit penurunan pada waktu operasi menit ke 45 . Hal ini disebabkan karena selama proses berlangsung kemampuan reaksi $\mathrm{Fe}$ terhadap manganese greensand dan zeolit semakin lama semakin berkurang dan akhirnya jenuh. Treatment menggunakan media manganese greensand terpadukan resin penukar ion mampu mengolah konsentrasi $\mathrm{Fe}$ yang awalnya melebihi baku mutu air bersih menjadi memenuhi baku mutu sesuai dengan PERMENKES 416/1990. Hasil treatment Fe menggunakan media zeolit terpadukan resin penukar ion belum mampu memenuhi baku mutu sesuai dengan PERMENKES 416/1990 sehingga diperlukan pengolahan lebih lanjut agar air baku tersebut layak digunakan sebagai sumber air bersih.

Hasil penurunan konsentrasi Fe dalam penelitian ini lebih efektif dari hasil penelitian sebelumnya. Anika (2013) dalam penelitiannya, menggunakan aerated filter dengan media zeolit berhasil mereduksi Besi sebesar $62 \%$, sedangkan dalam penelitian ini penurunan konsentrasi $\mathrm{Fe}$ menggunakan media zeolit berhasil mereduksi $\mathrm{Fe}$ sebesar $75 \%$. Faktor pendukung yang menyebabkan mengapa penurunan konsentrasi $\mathrm{Fe}$ dalam penelitian ini lebih efektif dari penelitian sebelumnya adalah karena menggunakan teknologi kombinasi antara filtrasi dengan resin penukar ion, sehingga diperoleh efektivitas removal yang tinggi untuk mengolah Fe.

\section{B. Grafik Efektivitas Removal Mn}

Gambar 4 berikut ini adalah grafik efektivitas removal $\mathrm{Mn}$ setelah treatment menggunakan media filtrasi manganese greensand dan zeolit terpadukan resin penukar ion :

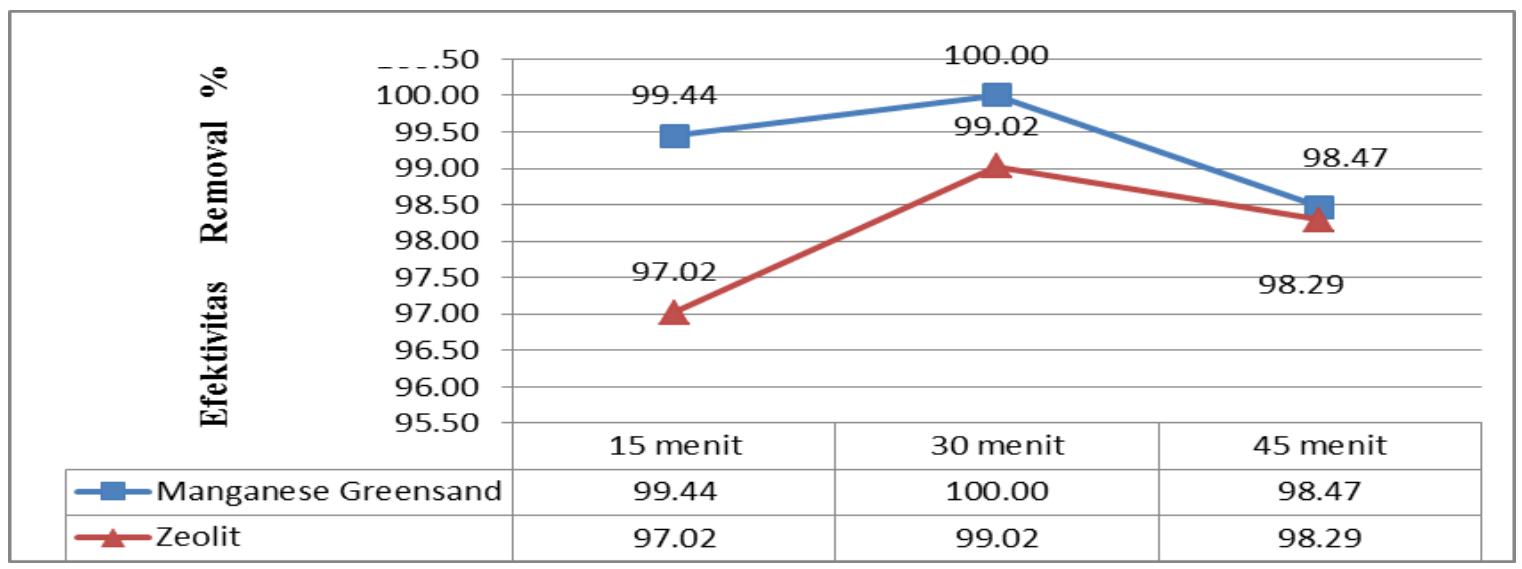

Gambar 4. Grafik Efektivitas Removal Mn

Gambar 4 menunjukkan efektivitas penurunan $\mathrm{Mn}$ menggunakan media manganese greensand dan zeolit terpadukan resin penukar ion. Media manganese greensand dan zeolit memiliki kesamaan yaitu waktu operasi paling optimal untuk menurunkan konsentrasi $\mathrm{Mn}$ adalah pada menit ke 30, sedangkan pada menit ke 45 terlihat sedikit mengalami penurunan. Pada media manganese greensand efektivitas removal Mn pada menit ke 30 adalah $100 \%$ namun pada menit ke 45 efektivitas removal Mn menjadi $98 \%$. Hal ini juga terjadi pada media zeolit, efektivitas removal Mn pada menit ke 30 adalah $99 \%$ namun pada menit ke 45 efektivitas removal Mn hanya 98\%. 
Berdasarkan efektivitas removal dapat disimpulkan bahwa media manganese greensand lebih efektif untuk menurunkan Mn daripada media zeolit. Hal ini disebabkan karena ukuran partikel media manganese greensand lebih kecil daripada partikel media zeolit. Namun secara umum kedua media tersebut efektif dalam menurunkan Mn karena mampu mengolah air baku yang awalnya melebihi baku mutu menjadi memenuhi baku mutu sesuai PERMENKES 416/1990 yakni konsentrasi maksimum Mangan adalah 0,5 $\mathrm{mg} / \mathrm{L}$.

Manganese greensand $\left(\mathrm{K}_{2} \mathrm{Z} . \mathrm{MnO}_{2}\right.$. $\mathrm{Mn}_{2} \mathrm{O}_{7}$ ) dapat berfungsi sebagai katalis dan pada waktu yang bersamaan besi dan mangan yang ada dalam air teroksidasi menjadi bentuk ferri - oksida dan mengoksida yang tak larut dalam air. Menurut Nusa Idaman Said (2003) reaksi kimianya adalah sebagai berikut :

$\mathrm{K}_{2} \mathrm{Z} \cdot \mathrm{MnO} \cdot \mathrm{Mn}_{2} \mathrm{O}_{7}+2 \mathrm{Mn}\left(\mathrm{HCO}_{3}\right)_{2} \rightarrow \mathrm{K}_{2} \mathrm{Z}+5 \mathrm{MnO}_{2}$ $+4 \mathrm{CO}_{2}+2 \mathrm{H}_{2} \mathrm{O}$

Sedangkan zeolit memiliki sifat sebagai adsorben dan penyaring molekul, hal ini dimungkinkan karena struktur zeolit yang berongga, sehingga zeolit mampu menyerap sejumlah besar molekul yang berukuran lebih kecil atau sesuai dengan ukuran rongganya. Endapan Mn yang terserap kemudian akan ditukar dengan kation pada unsur logam golongan IA atau IIA (alkali dan alkali tanah) seperti $\mathrm{K}^{+}, \mathrm{Na}^{+}, \mathrm{Ca}^{+}$dan $\mathrm{Mg}^{2+}$. Persamaan reaksi pertukaran ion pada zeolit yaitu :

Zeolit. $\mathrm{Na}^{+}+\mathrm{Mn}^{2+} \rightarrow$ Zeolit. $\mathrm{Mn}^{2+}+\mathrm{Na}^{+}$

Gambar 4 juga menjelaskan bahwa efisiensi removal $\mathrm{Mn}$ menggunakan media manganese greensand dan zeolit terpadukan resin penukar ion mengalami sedikit penurunan pada waktu operasi menit ke 45 . Hal ini disebabkan karena selama proses berlangsung kemampuan reaksi Mn terhadap manganese greensand dan zeolit semakin lama semakin berkurang dan akhirnya jenuh. Dalam penelitian ini secara umum media manganese greensand dan zeolit lebih efektif menurunkan konsentrasi Mn daripada konsentrasi Fe. Hal ini dapat berhubungan dengan karakteristik dari Fe dan Mn yaitu jarijari atom. Mangan dan Besi berada dalam satu periode pada tabel periodik unsur yaitu periode 4 yang merupakan unsur-unsur transisi. Nomor atom Mangan adalah 25 sedangkan 26 untuk Besi. Besarnya jari-jari atom dipengaruhi oleh besarnya nomor atom unsur tersebut. Di dalam satu periode, semakin unsur ke kanan maka jari-jari atomnya semakin kecil. Sehingga dapat dikatakan bahwa ukuran logam besi lebih kecil dari mangan. Hal ini dapat menyebabkan logam $\mathrm{Fe}$ yang berupa endapan dalam air akan lolos dan tidak tersaring oleh tiap media yang digunakan (Anika,2013). Selain itu penyebab media zeolit lebih efektif menurunkan konsentrasi $\mathrm{Mn}$ daripada konsentrasi $\mathrm{Fe}$ adalah seperti yang telah dijelaskan oleh Fach et al. (dalam Abdurahman 2004) bahwa zeolit dapat mengikat $\mathrm{Fe}$ dengan membentuk senyawa koordinasi. Aluminosilkat, sebagai bagian struktur zeolit $\mathrm{M}_{2 / \mathrm{n}} \mathrm{O} . \mathrm{Al}_{2} \mathrm{O}_{3 \cdot \mathrm{y}} \mathrm{SiO}_{2 \cdot \mathrm{w}} \mathrm{HO}$, berfungsi sebagai ligan. Ligasi Mn lebih sukar terjadi dibandingkan dengan $\mathrm{Fe}$ karena $\mathrm{Mn}$ mempunyai ukuran lebih besar dari pada $\mathrm{Fe}$ (nomor atom Mn 26 dan Fe 27). Karena itu zeolit lebih mudah mengikat Mn daripada Besi $(\mathrm{Fe})$.

\section{KESIMPULAN}

Penurunan kadar $\mathrm{Fe}$ dan $\mathrm{Mn}$ menggunakan media manganese greensand terpadukan resin penukar ion menghasilkan efektivitas removal $\mathrm{Fe}$ sebesar 94\% dan $99 \%$ untuk removal $\mathrm{Mn}$. Konsentrasi Fe setelah treatment menggunakan media manganese greensand terpadukan resin penukar ion adalah $0,316 \mathrm{mg} / \mathrm{L}$ dan $0,017 \mathrm{mg} / \mathrm{L}$ untuk $\mathrm{Mn}$. Konsentrasi tersebut telah memenuhi baku mutu air bersih sesuai dengan PERMENKES 416/1990. Sedangkan efektivitas removal Fe menggunakan media zeolit terpadukan resin penukar ion adalah $73 \%$ dan efektivitas removal $\mathrm{Mn}$ adalah 98\%. Konsentrasi $\mathrm{Fe}$ setelah treatment menggunakan media manganese greensand terpadukan resin penukar ion adalah $1,424 \mathrm{mg} / \mathrm{L}$ dan 0,049 $\mathrm{mg} / \mathrm{L}$ untuk Mn. Konsentrasi Mn telah memenuhi baku mutu air bersih sesuai dengan PERMENKES 416/1990.

\section{Ucapan Terima Kasih}

Ucapan terima kasih disampaikan kepada seluruh staf pengajar Program Studi Teknik Lingkungan Universitas PGRI Adi Buana Surabaya yang telah mengizinkan dan mendukung peneliti untuk melakukan penelitian di Workshop dan Laboratorium Teknik Lingkungan Universitas PGRI Adi Buana Surabaya. 
Novia Rahmawati dan Sugito : Reduksi Besi (Fe) dan Mangan (Mn) pada Air Tanah Menggunakan Media Filtrasi Manganese Greensand dan Zeolit Terpadukan Resin

\section{DAFTAR PUSTAKA}

Abdurahman dan Hartono, B. Juni 2004. Penyaringan Air Tanah Dengan Zeolit Alami Untuk Menurunkan Kadar Besi dan Mangan. Depok : Makara, Kesehatan, Vol. 8, No. 1, Juni 2004: 1-6 Fakultas Kesehatan Masyarakat Jurusan Kesehatan Lingkungan Universitas Indonesia

Anika. 2013. Pengaruh Jenis Media Pada Aerated Filter Terhadap Penurunan Kadar Besi Dan Mangan Air Sumur Gali. Surabaya : Program Studi S-1 Ilmu dan Teknologi Lingkungan, Departemen Biologi Fakultas Sains dan Teknologi, Universitas Airlangga

Cheetam, D., A.1992. Solid State Compound, England : Oxford University Press, 234-237

Crossgrove, J., dan Wei Zheng. 2004. Review article : Manganese toxicity uponoverexposure. NMR Biomed, 17, $544-553$

Fach E, Waldman WJ, Williams M, Long J, Meister RK, Dutta PK. 2002. Analysis Of The Biological And Chemical Reactivity Of Zeolit-Based Aluminosilicate Fibers And Particulates 110: 1087-1096. Environ Health Perspect

http://dispendukcapil.surabaya.go.id/index.php. 2013. Jumlah Penduduk Kota Surabaya Tahun 2013 (diakses tanggal 11 November 2014)

http://surabayakota.bps.go.id/subject/table/101 Statis. 2013. Persentase Rumah Tangga Menurut Sumber Air Minum Tahun 2013. (diakses tanggal 11 November 2014)

http://www.lenntech.com/processes/iron-manganese/iron/iron-removal physical chemicalway.htm. Iron Removal By Physical-Chemical Ways. (diakses tanggal 11 November 2014)

Lenore S. Clescerl, Andrew D. Eaton, Eugene W. Rice . 2005. Standard Methods for Examination of Water \& Wastewater (21st ed.). Washington DC: American Public Health Association

Peraturan Menteri Kesehatan No. 416 Tahun 1990 Tentang : Syarat-syarat dan Pengawasan Kualitas Air

Purwanti. 2010. Laju Reaksi. Yogyakarta : Universitas Negeri Yogyakarta

Said, N. I. .2003. Metoda Praktis Penghilangan Zat Besi dan Mangan di Dalam Air Minum. Jakarta : Kelair BPPT. 2003

Sugito dan Sembodo, B. P. 2014. Water Treatment Based on ion Exchange Membrane Permeable Combined with The Field Electrodeionization, Journal of Civil and Environmental Research, IISTE, ISSN 2224-5790 (print), Vol 6 No 12, p ; 10 - 15

Winda, K. S. dan Nieke K. 2002. Studi Penurunan Besi (Fe) dan Mangan (Mn) Dengan Menggunakan Cascade Aerator Dan Rapid Sand Filter Pada Air Sumur Gali. Surabaya : Jurusan Teknik Lingkungan - FTSP Institut Teknologi Sepuluh Nopember. 